\title{
The Regulation of Retail Investment Services in the EU: Towards the Improvement of Investor Rights?
}

\author{
Olha O. Cherednychenko
}

Received: 8 February 2010 / Accepted: 15 September 2010 /

Published online: 2 October 2010

(C) The Author(s) 2010. This article is published with open access at Springerlink.com

\begin{abstract}
Despite the fact that a substantial body of European Community (EC) law already exists to protect retail investors, the markets in retail investment services and products in the EU remain fragmented. Moreover, the recent financial crisis has undermined investor confidence in financial markets more generally, and "packaged" retail investment products (PRIP), such as investment funds or life insurance policies, in particular. To rebuild retail investor confidence in PRIP by empowering retail investors to make active use of their rights, in 2009 the European Commission proposed to extend the provisions of the 2004 Markets in Financial Instruments Directive (MiFID) to PRIP. Is the MiFID, however, fit for the purpose which the Commission has in mind? This contribution explores to what extent the MiFID actually confers rights on retail investors and empowers them to make use of these rights. The author concludes that investor rights and remedies should be taken more seriously when making European financial services law. The current overhaul of the EC legal framework for the provision of investment services provides a good opportunity to do so.
\end{abstract}

Keywords EC securities regulation · Retail investment services · Investor protection · Investor rights $\cdot \mathrm{MiFID}$

\section{Introduction}

Financial services, in particular investment services, have become an essential part of the everyday life of EU citizens. Such services facilitate citizens' full participation in the economy, enabling them to plan for the long term and protecting them from unforeseen changes in circumstances. Financial services are also of great significance for the EU economy. A single market in financial services, which has been the overall EU objective in the last decade, would "act as a catalyst for economic growth across all sectors of the

O. O. Cherednychenko $(\square)$

Centre for Law and Governance, Faculty of Law, VU University Amsterdam, De Boelelaan 1105,

1081 HV Amsterdam, The Netherlands

e-mail: o.o.cherednychenko@vu.nl 
economy, boost productivity, and provide lower cost and better quality financial products for consumers and enterprises." 1 The growing economic importance of financial services is reflected in a great number of regulatory initiatives that have been undertaken in this area by the EU in the last decade. Whereas initially the EU focused mainly on regulating the wholesale financial market, ${ }^{2}$ in recent years the emphasis in the EU policy has shifted considerably towards the integration of retail (consumer) financial markets. ${ }^{3}$

One of the areas where European integration has been actively sought is the market for retail investment services. Such services involve the supply of financial instruments (such as shares or bonds) or investment products (such as investment insurance), and services (such as investment advice), by one party (an investment service provider, such as an investment firm or a credit institution) to another party (a client, i.e., a retail investor (consumer)).

At present, retail investment services are subject to a number of both cross-sectoral and sector-specific measures (to be) adopted by the European Community with a view to protecting consumers. Recent cross-sectoral European Community (EC) measures of a more general character include the Distance Marketing of Consumer Financial Services Directive, ${ }^{4}$ the Unfair Commercial Practices Directive, ${ }^{5}$ and the proposal for a Consumer Rights Directive. ${ }^{6}$ These horizontal instruments contain rules targeting inter alia misleading and aggressive commercial practices and the use of unfair standard contract terms in the whole financial sector and beyond, which should also be observed by investment service providers. ${ }^{7}$ Yet, the main body of rules governing the provision of investment services, including investor protection rules, is currently contained in the sector-specific legislation. The regulation of investment services in general is dominated by the Markets in Financial

\footnotetext{
${ }^{1}$ Conclusion of a discussion among economy and finance ministers, the ECB president and governors of National Central Banks, at the informal ECOFIN meeting in Brussels in April 2002, in a report on financial integration drawn up by a Working Group of the Economic and Financial Committee (EFC).

${ }^{2}$ Financial Service Action Plan 1999-2005 (FSAP). Documents relating to the FSAP can be found at $<\mathrm{http}$ :// ec.europa.eu/internal_market/finances/actionplan/index_en.htm\#documents>.

${ }^{3}$ White Paper on Financial Services 2005-2010, COMM (2005) 629; Green Paper on Retail Financial Services, COM (2007) 226; Initiatives in the Area of Retail Financial Services: Accompanying Document to the Communication from the Commission to the European Parliament, the Council, the European Economic and Social Committee and the Committee of the Regions (COM, 2007) 724 final; Communication from the Commission to the European Parliament, the Council, the European Economic and Social Committee and the European Central Bank on Regulating Financial Services for Sustainable Growth, COM (2010) 301 final, pp. 6-7. See also the recent speeches by the new EU Commissioner for the internal market and services Michel Barnier, in particular, "Forging a New Deal between Finance and Society: Restoring Trust in the Financial Sector" at the European Financial Services Conference, Brussels, 26 April 2010 and "A New Ambition for the European Market" at the European Parliament's Internal Market and Consumer Protection Committee, Brussels, 28 April 2010.

${ }^{4}$ Directive 2002/65/EC of the European Parliament and of the Council of 23 September 2002 concerning the distance marketing of consumer financial services and amending Council Directive 90/619/EEC and Directives 97/7/EC and 98/27/EC, OJ L 271/16.

${ }^{5}$ Directive 2005/29/EC of the European Parliament and of the Council of 11 May 2005 concerning unfair business-to-consumer commercial practices in the internal market and amending Council Directive 84/450/ EEC, Directives 97/7/EC, 98/27/EC and 2002/65/EC of the European Parliament and of the Council and Regulation (EC) No 2006/2004 of the European Parliament and of the Council, OJ L 149/22.

${ }^{6}$ Proposal for a Directive of the European Parliament and of the Council on Consumer Rights COM (2008) 614. The proposal is the result of the review of the Consumer Acquis which covers four directives on consumer protection: Directive 85/577/EEC on contracts negotiated away from business premises, Directive 93/13/EEC on unfair terms in consumer contracts, Directive 97/7/EC on distance contracts, Directive 1999/ 44/EC on consumer sales and guarantees.

${ }^{7}$ The Draft Directive on Consumer Rights is applicable to contracts relating to financial services only in so far as they are not covered by the existing Community legislation on consumer financial services (Recital 11). For the purposes of the Draft Directive, a "financial service means any service of a banking, credit, insurance, personal pension, investment or payment nature" (art. 2 (13)).
} 
Instruments Directive (MiFID), ${ }^{8}$ which has been described as Europe's "new constitution" in the area of investment services and secondary capital markets (Grundamann and Hollering 2008, pp. 58-59). ${ }^{9}$

Despite the fact that a substantial body of EC law already exists to protect retail investors, the markets in retail investment services and products in the EU remain fragmented. ${ }^{10}$ On the one hand, investment firms and credit institutions are reluctant to engage in cross-border retail investment services. On the other hand, consumers are reluctant to buy investment services and products abroad. Moreover, the recent financial crisis has undermined investor confidence in financial products and markets more generally. While retail investment in the financial markets is currently largely channeled through "packaged" retail investment products (PRIP), such as investment funds or life insurance policies, assets invested in such products have declined from 10 trillion $€$ at the end of 2007 to estimates of around $8 €$ at the end of $2008 .^{11}$

According to the European Commission, " $\mathrm{t}$ ] he financial crisis has provided a stark reminder of the importance of transparency in financial products and of the potential costs of irresponsible selling. A collapse in investor confidence has underlined the urgency of ensuring the right regulatory framework is in place, so that the rebuilding of confidence can occur on a sound basis." 12 To rebuild retail investor confidence in PRIP, in 2009 the Commission launched the review of the EC investor protection measures currently in place. ${ }^{13}$ The Commission's view is that the existing legal requirements on product transparency, sales and advice differ according to the legal form investment products take and the channel through which they are sold; moreover, some products and distribution channels are not currently addressed by EC law at all. Consequently, the legal framework for investment services currently in place does not provide "a coherent basis for the protection of the retail investor or for the balanced development of the market for packaged retail investment products." 14

In the words of Emil Paulis, Director of the Financial Services Policy and Financial Markets Directorate, the main purpose of the overhaul of the current EC investor protection measures can be seen as "empowering investors to make adequate use of their rights." 15 To

\footnotetext{
${ }^{8}$ Directive 2004/39/EC of the European Parliament and of the Council of 21 April 2004 on markets in financial instruments amending Council Directives 85/611/EEC and 93/6EEC and Directive 2000/12/EC of the European Parliament and of the Council and repealing Council Directive 93/22/EEC, OJ L 145/1. See also Directive 2006/73/EC of the EC Commission of 10 August 2006 implementing Directive 2004/39/EC of the European Parliament and of the Council as regards organizational and operating conditions for investment firms and defined terms for the purposes of that Directive, OJ L 241/26.

${ }^{9}$ Primary markets are involved in bringing securities to the market for the first time and transactions between the issuer seeking capital and the investor providing capital. Secondary markets involve all transactions in securities which take place after their issue, or after the initial distribution. Both the stock exchange market and the markets outside the stock exchanges are considered to belong to the secondary markets in securities. ${ }^{10}$ Green Paper on Retail Financial Services, COM (2007) 226.

${ }^{11}$ Communication from the Commission to the European Parliament and the Council on Packaged Retail Investment Products, COM (2009) 204 final, p. 2 (referred to below as Commission Communication on PRIP).

12 Commission Communication on PRIP, p. 2.

${ }^{13}$ Commission Communication on PRIP. The Commission's intention to present legislative proposals on packaged retail investment products has recently been confirmed in the Communication from the Commission to the European Parliament, the Council, the European Economic and Social Committee and the European Central Bank on Regulating Financial Services for Sustainable Growth, COM (2010) 301 final, p. 7 .

${ }^{14}$ Commission Communication on PRIP, p. 2.

${ }^{15}$ Summary of the Technical Workshop on Packaged Retail Investment Products, 22 October 2009, available at <http://ec.europa.eu/internal_market/finservices-retail/docs/investment_products/minutes-prips-workshop221009 en.pdf>, p. 2 (italics added).
} 
empower retail investors to do so, the Commission proposes to replace the existing sectoral patchwork by a horizontal cross-cutting approach to mandatory disclosures and selling practices, so that the same legislative requirements would apply to all sales of PRIP, irrespective of the distribution channel employed. In the view of the Commission, the MiFID provisions on conduct of business rules "offer a clear benchmark for such requirements." 16

Against this background, the question which will be addressed in this contribution is to what extent the MiFID provisions on conduct of business rules, which the European Commission proposes to extend to all PRIP, actually confer rights on retail investors and empower them to make use of these rights. For this purpose, I will first discuss the purport of the conduct of business rules regime laid down by the MiFID. Subsequently, I will turn to the analysis of the implications of this regime for the empowerment of retail investors ("The Implications of the MiFID Conduct of Business Regime for Retail Investor Empowerment") and the role of general private law in protecting such investors ("The Role of Private Law in Protecting Retail Investors"). I will conclude by stressing the need to take retail investor rights more seriously when making European financial services law (“Concluding Remarks").

\section{The Purport of the MiFID Conduct of Business Regime}

\section{Contract-Related Conduct of Business Rules}

One of the important aspects of the MiFID is the introduction of an extensive catalogue of substantive requirements - the so-called "conduct of business rules"-governing the provision of investment services to their recipients at the pre-contractual and contractual stages. Apart from the overall objective of the market integration, the conduct of business regime has the twofold aim of ensuring a high level of investor protection and the integrity and overall efficiency of the financial system.

The MiFID conduct of business rules build upon the broadly formulated principles laid down by art. 11 of its predecessor - the Investment Services Directive (ISD) ${ }^{17}$ : the loyalty principle (any investment service provider must act honestly and fairly in the best interests of its (potential) clients), the informed consent principle (the investment service provider must adequately disclose relevant material information when dealing with its (potential) clients), and the "know your client" principle (the investment service provider must seek from its (potential) clients information regarding their financial situation, investment experience and objectives as regards the services requested).

Articles 18-24 of the MiFID considerably clarify and supplement these principles. The core of the conduct of business rules under the MiFID is formed by the general duty of loyalty; the duty to provide clear, fair, and not misleading information; various disclosure obligations, in particular concerning the risks involved in a particular investment service or product and concerning the conflict of interests; the duty to know one's client and to ensure the "appropriateness" or "suitability" of an investment service, financial instrument, or investment product to one's client; the duty to ensure "best execution" of the client's order. ${ }^{18}$

\footnotetext{
${ }^{16}$ Commission Communication on PRIP, p. 10.

${ }_{17}^{17}$ Council Directive 93/22/EEC of 10 May 1993 on investment services in the securities field, OJ L 141/27.

18 The meaning of these rules is further fleshed out in arts. 21, 22, 24, 26-50 of the Directive 2006/73/EC implementing the MiFID.
} 
The extent to which the conduct of business rules are applicable depends on the nature of a (potential) client. The MiFID requires Member States to oblige investment service providers to classify their (potential) clients into three categories: professional clients, retail clients, and eligible counterparties. ${ }^{19}$ Professional clients are institutional investors, such as credit institutions, investment firms or pension funds, which are required to be authorized or regulated to operate in the financial markets. Retail clients are all those clients which do not fall under the category of professional clients. Finally, eligible counterparties are clients who may be treated as professional by the investment service provider on request and may thus waive certain protections afforded by the conduct of business rules. It is worth noting that under the MiFID retail investors may also be treated as professional clients provided that they meet certain requirements concerning the expertise, experience, and knowledge in the investment field. ${ }^{20}$ Apart from this limited category of retail investors who may waive certain protections, investment service providers should normally observe the conduct of business rules in their dealings with retail investors, if necessary against the will of such investors.

\section{Maximum Harmonization of Conduct of Business Rules}

Initially the EC pursued only a minimum harmonization of the conduct of business rules in Europe. Under the 1993 ISD Member States were allowed to exceed the level of investor protection envisaged in this Directive. Moreover, due to the fact that the principles of business conduct introduced by art. 11 of the ISD operated on a high level of generality, the level of harmonization induced thereby was quite modest, as different rules could be perfectly compatible with these broad principles. ${ }^{21}$

In contrast to its predecessor, however, the MiFID generally aims to bring about a maximum harmonization of the rules concerning investment services and activities in the securities field, including the conduct of business rules. Member States are allowed to retain or impose requirements additional to those in this Directive only in exceptional cases. ${ }^{22}$ While some detailed provisions on conduct of business rules, in particular the duty to know one's client when providing execution-only services, are

\footnotetext{
${ }^{19}$ The Directive 2006/73/EC implementing the MiFID provides further clarity as to what rules are applicable to each client category.

${ }^{20}$ According to Annex II (II.1) of the MiFID, a retail investor can waive certain protections afforded by the conduct of business rules if he meets at least two of the following three criteria: (a) the investor has carried out transactions, in significant size, on the relevant market at an average frequency of 10 per quarter over the previous four quarters; (b) the size of the investor's financial instrument portfolio, defined as including cash deposits and financial instruments exceeds 500,000€; (c) the investor works or has worked in the financial sector for at least 1 year in a professional position, which requires knowledge of the transactions or services envisaged.

${ }^{21}$ On the implementation of the ISD I in the EU Member States in general, see, e.g., Tison 2002.

${ }^{22}$ See, in particular, art. 4 of the Commission Directive 2006/73/EC implementing the MiFID: "Member States may retain or impose requirements additional to those in Directive 2006/73/EC in exceptional cases where such requirements are objectively justified and proportionate so as to address specific risks to investor protection or to market integrity that are not adequately addressed by the Directive and provided that the specific risks addressed by the requirements are of particular importance in the circumstances of the market structure of that Member State." Notwithstanding the "exceptional" impact of the recent financial crisis, this provision was hardly used by the Member States to impose requirements additional to those in the MiFID and the Implementing Directive, to a large extent due to the difficulties involved in justifying such measures before the Commission.
} 
the result of political compromises between Member States, the latter may provide for neither more nor less protective conduct of business rules.

The current policy reflected in the MiFID is based on the assumption that retail investors in the EU deserve the same level of protection all over the EU, and that the EC conduct of business rules fit to the needs of retail investors in each Member State. One may doubt, however, to what extent the maximum harmonization approach is consistent with the idea of the empowerment of investors to make active use of their rights, considering that the economic, social and cultural needs of non-professional investors may differ from one Member State to another. One of the most important questions that should be asked is whether the needs of non-professional investors in countries with highly developed capital markets, such as the UK, are the same as the needs of non-professional investors in post-communist countries with largely underdeveloped capital markets, such as Romania. In so far, the export of the Western type of the EC securities regulation to the New Member States has not been studied in the context of the economic, social and local needs of these countries (Cherednychenko 2010).

\section{Conduct of Business Rules as Supervision Standards}

Although the MiFID contains mandatory contract-related rules for the conduct of business by investment service providers, it is notable that these rules are not written for and from the perspective of the private law relationship between the investment firm or credit institution and the (retail) investor (Micklitz 2004, p. 324). In contrast, for example, to the Draft Directive on Consumer Rights which explicitly confers rights on consumers against businesses and, albeit to a limited extent, provides consumers with remedies, ${ }^{23}$ the MiFID is not drafted in such terms. The MiFID does not explicitly grant rights to retail investors as regards conduct of business rules or contain remedies empowering such investors to take action in those cases where an investment firm or a credit institution does not comply with the conduct of business rules. ${ }^{24}$ In this respect, the MiFID also differs from the Distance Marketing of Consumer Financial Services Directive applicable inter alia to distance selling of consumer investment services, and more recent sector-specific directives related to the provision of other (consumer) financial services, such as the Payment Services Directive ${ }^{25}$ and the Consumer Credit Directive. $^{26}$ Unlike the MiFID, the contract-related rules in these three measures are drafted from the perspective of the private law relationship between a consumer and a service provider and do include inter alia consumer rights; ${ }^{27}$ moreover, the Payment

\footnotetext{
${ }^{23}$ E.g., the consumer's right of withdrawal for distance and off-premises contracts (ch. III), consumer rights specific to sales contracts (ch. IV), consumer rights concerning contract terms (ch. V).

${ }^{24}$ The only provisions of the MiFID which deal with private enforcement-arts. 52(2b) and 53-are discussed in more detail below.

${ }^{25}$ Directive 2007/64/EC of the European Parliament and of the Council of 13 November 2007 on payment services in the internal market amending Directives 97/7/EC, 2002/65/EC, 2005/60/EC and 2006/48/EC and repealing Directive 97/5/EC, OJ L 319/1.

${ }^{26}$ Directive 2008/48/EC of the European Parliament and of the Council of 23 April 2008 on credit agreements for consumers and repealing Council Directive 87/102/EEC, OJ L 133/66.

${ }^{27}$ E.g., the consumer's right of withdrawal (art. 6 of the Distance Marketing of Consumer Financial Services Directive; art. 14 of the Consumer Credit Directive); the consumer's right to early repayment (art. 16 of the Consumer Credit Directive); the payer's right to a refund for payment transactions initiated by or through a payee (art. 62 of the Payment Services Directive).
} 
Services Directive, for example, also extensively deals with service provider liabilities to consumers. $^{28}$

As a matter of fact, both the ISD and the MiFID are drafted predominantly from the perspective of public enforcement of the investor protection provisions contained therein via supervisory authorities (Grundmann-van de Krol 2002, p. 4; Micklitz 2004, p. 324). The extensive conduct of business regime established by the MiFID is directed at ensuring the effective supervision over the compliance by investment service providers with the new supervision standards. The provider which does not comply with the conduct of business rules must be subject to administrative sanctions which must be effective, proportionate and dissuasive (art. 51 of the MiFID). To ensure the effective administrative enforcement of the MiFID, Member States should establish public authorities (art. 48(2) of the MiFID). Imposing supervision standards upon investment service providers and ensuring their public enforcement have currently been seen by the EU legislator as the primary means of achieving its regulatory objectives in the field of investment services and activities, including a high level of investor protection.

Against this background, it is not surprising that the MiFID, including the extensive contract-related conduct of business rules contained therein, was implemented by Member States not within the civil codes or consumer protection legislation but within the financial supervision legislation. As a result, the conduct of business rules as supervision standards whose compliance must be checked by supervisory authorities are generally considered to be of a public law nature (e.g., Van Baalen 2007, p. 661; Ferrarini 2005, p. 21; Fuchs 2009, p. 1194; Grundmann-van de Krol 2002, p. 2; Koller 2009, p. 1254; Köndgen 1998, p. 117; Micklitz 2004, p. 324).

\section{The Implications of the MiFID Conduct of Business Regime for Retail Investor Empowerment}

\section{Direct/Indirect Effect}

The purport of the MiFID conduct of business regime gives cause for reflection concerning the empowerment of individual non-professional investors to stand up for their rights. Considering that conduct of business rules are standards of financial supervision, the first question which needs to be answered is whether these rules have any effect in the private law relationship between the investment firm or credit institution and the (potential) client. Can the investor invoke the conduct of business rules directly? ${ }^{29}$ Or does he have to ground his claim in the existing private law causes of action, and if so, to what extent do the conduct of business rules help him in doing so? In the absence of clear guidelines concerning the private enforcement of the EC securities regulation by the aggrieved investors or their groups, in particular remedies available to them, Member States have a wide discretion as to how to deal with it. It does not come as a surprise, therefore, that there

\footnotetext{
${ }^{28}$ E.g., the payment service provider's liability to the payer for unauthorized payment transactions (art. 60); the payment services provider's liability to the payer for non-execution or defective execution of the payment transaction (art. 75).

${ }^{29}$ Such an approach has been advocated, for example, by Reich who argues that although the MiFID conduct of business rules are predominantly of a public law nature, they may nevertheless be interpreted in the sense that they also confer subjective rights on individual investors vis-à-vis investment service providers (Reich 2010b).
} 
are differences between Member States concerning the effect of the conduct of business rules as between the investment service provider and its (potential) client.

First of all, legal systems approach differently the issue of whether supervision standards may have direct effect in private law. In the UK, for example, the supervision standards can be directly invoked by private parties who have suffered loss as a result of their breach by the investment firm or credit institution. This has become possible because the Financial Services and Markets Act 2000 makes frequent use of the technique of expressly conferring a statutory right of action upon designated persons pursuant to Section 150 of the Act where loss has been suffered as a result of a breach of duty under the Act or delegated legislation or other rules made under its aegis. The Financial Services Authority has decided that a right of action would be available to a private person in respect of any rule within the Conduct of Business Source Book. ${ }^{30}$ In contrast, in many other legal systems, in particular, in Germany and the Netherlands, conduct of business rules do not have direct effect between the investment service provider and its (potential) client, and hence they cannot be directly invoked by the aggrieved retail investor.

Secondly, it seems to be undisputed today that the regulatory conduct of business rules may have indirect effect between the investment service provider and its (potential) client. In many legal systems, the conduct of business rules have already been exercising a radiating effect (Ausstrahlungsswirkung) on the content of the private law concepts. ${ }^{31}$ In German law, for example, the conduct of business rules contained in the Securities Trading Act (Wertpapierhandelsgesetz $(W p H G)) 1994$ specify the meaning of more general private law concepts, such as good faith (Treu und Glauben) contained in Section 242 of the Civil Code, the commission agent's duty of loyalty (Pflicht zur Interessenwahrung) laid down in Section 348 of the Commercial Code or pre-contractual duties which can be based on Section 311(2) of the Civil Code. ${ }^{32}$ In Dutch law, the private law concepts, such as the service provider's general duty of care (zorgplicht van een goed opdrachtnemer) embodied in article 7:401 of the Civil Code, serve as an umbrella under which the conduct of business rules laid down in or pursuant to the Financial Supervision Act (Wet financieel toezicht (Wft) 2007 enter into contract law. ${ }^{33}$ Also in English law the conduct of business rules, which are now contained in the Conduct of Business Sourcebook enacted by the Financial Services Authority, ${ }^{34}$ have become highly influential in shaping the common law standards of care, in particular the scope of the duty of care in the tort of negligence. ${ }^{35}$

\footnotetext{
${ }^{30}$ FSA PS 45, para. 3.47 .

${ }^{31}$ On this in more detail, see Cherednychenko 2007, Chapters 7 and 8.

32 See, for example, BGH 11 November 2003, WM 2004, 24, 26; BGH 8 May 2001, 22, ZIP 2001, 1580, 1581; BGH 5 October 1999, BGHZ 142, 345, 346.

${ }^{33} \mathrm{See}$, in particular, the case law of the alternative dispute resolution boards in the field of financial services - the Dutch Securities Institute Complaints Board (Klachtencommissie DSI (KCD)) and the Appeal Commission of the Dutch Securities Institute (Commissie van Beroep (KHCB)), as well as their successor-the Financial Services Disputes Board (Geschillencommissie financiële dienstverlening) of the Financial Services Complaints Institute (Klachteninstituut Financiële Dienstverlening (Kifid)). E.g. KHCB 30 July 2002, JOR 2002/165; KCD 30 July 2003, no. 107; KCD 16 December 2005, 05-282.

34 The FSA has extensive statutory powers to make rules under the Financial Services and Markets Act (FSMA) 2000 (ss. 138-148).

35 See, for example, Lloyd Cheyham \& Co. Ltd v. Eversheds [1985] 2 Lloyd's Rep. P.N. 154; Bankers Trust International PLC v. PT Dharmala Sakti Sejahtera [1996] CLC 518; Gorham \& Others v. British Telecommunications plc, Trustees of the BT Pension Scheme, \& Standard Life Assurance Company [2000] 1 WLR 2129; Brandeis (Brokers) Ltd v. Black and others [2001] 2 All ER (Comm) 980; Loosemore v. Financial Concepts (a firm) [2001] Lloyd's Rep. P.N. 235; Seymour v. Caroline Ockwell \& Co [2005] 39 P. N.L.R. 758.
} 
However, there are considerable differences between Member States concerning the conditions under which supervision standards may have indirect effect in the investment service provider-client relationship. The answer to this question largely depends on national private laws. In order to have indirect effect, supervision standards should always fit in the private law concepts.

In English law, for example, a supervision standard will have a radiating effect in common law only if the claimant succeeds in establishing that a duty of care corresponding to the supervision standard should be recognized at common law. ${ }^{36}$

In the Netherlands, the effect of supervision standards in private law is in the first place subject to the "relativity," or "proximity," requirement laid down in art. 6:163 of the Civil Code. According to this requirement, the violation of a legal rule will only lead to liability towards persons alleging damages as a consequence of this violation if the said rule is intended to protect their interests. ${ }^{37}$ The relativity plays a decisive role in determining whether the violation of a certain supervision standard contained in the Financial Supervision Act 2007 has effect in the investment service provider-client relationship via general private law concepts, such as the general duty of care in tort or contract embodied in arts. 6:162 and 7:401 of the Civil Code, respectively. ${ }^{38}$ For example, the rules laid down in or pursuant to Part IV of the Act, which implement art. 19 of the MiFID concerning the investment service providers' conduct of business obligations, clearly aim to protect investors and hence they have effect in private law. The "relativity"-test, however, does not always lead to a clear-cut outcome. This is in particular the case with certain rules concerning the management of an investment firm contained in the Further Regulations on Conduct Supervision of Financial Firms (Nadere regeling gedragstoezicht financiële ondernemingen) 2006 (Supplement 9) currently in force because such rules may have the elements of both prudential and conduct supervision (Van Baalen 2007, p. 666). It is unclear, for instance, whether the rules concerning the client order handling and records have effect in private law (Supplement 9, art. 9.15 of the Further Regulations).

A similar requirement of relativity also exists in German tort law under Section 823 of the German Civil Code. In order to base the liability of the investment service provider in tort, the (potential) client must prove that the supervision rule contained in the Securities Trading Act, which allegedly has been breached, not only serves the general interest, but also his individual interest. It is notable, however, that contrary to the prevailing view in the literature, ${ }^{39}$ in its recent case law, the German Supreme Court in private law matters appears to be reluctant to give effect to the conduct of business rules contained in the Securities Trading Act on the basis of Section 823 of the Civil Code. In one of the cases decide by it, the facts of which relate to the conduct of business rules as laid down Section $31 \mathrm{ff}$. of the Act prior to the implementation of the MiFID, the Supreme Court did recognize the investor protection function of these rules; nonetheless, it denied that the conduct of business rules can be qualified as the rules protecting the investors' individual interests in the sense of Section 823 of the Civil Code. ${ }^{40}$ According to the Court, individual claims for

\footnotetext{
${ }^{36}$ See, for example, Loosemore v. Financial Concepts (a firm) [2001] Lloyd's Rep. P.N. 235; Seymour v. Caroline Ockwell \& Co [2005] 39 P.N.L.R. 758. See also Michael Martin \& Another v. Britannia Life Limited [2000] Lloyd's Rep. P.N. 412.

${ }^{37}$ See the Explanation in Parlementaire Geschiedenis Boek 6, p. 615.

${ }^{38}$ Although the concept of relativity is best known in tort law, in Dutch private law it is also highly relevant for the effect of the public law norms in contractual relationships.

${ }^{39}$ See Fuchs 2009, p. 1206, with further references to the extensive literature.

${ }^{40}$ BGH 19 February 2008, BKR 2008, 294.
} 
damages as a result of the violation of the conduct of business rules do not make sense and are unacceptable considering the whole system of liability. ${ }^{41}$

At the same time, such a restrictive approach of the German Supreme Court to liability in tort on the basis of Section 823 of the Civil Code, does not seem to preclude the aggrieved (potential) client from invoking other private law concepts as the legal basis for the investment firm's or credit institution's liability for the violation of the conduct of business rules in the investment service provider-client relationship. In particular, the conduct of business rules may have a radiating effect upon the content of Section 311(2) which may provide the basis for pre-contractual duties, Section 280(1) of the Civil Code concerning the violation of a contractual duty or $\S 826$ of the Civil Code concerning intentionally causing damage in a manner violating good morals (Fuchs 2009).

\section{Procedural Difficulties to Retail Investors}

Furthermore, even if a particular supervision standard may, whether directly or indirectly, have effect in the relationship of investment service provider and its client, this does not imply yet that the aggrieved retail investor has a real chance to obtain relief. Whether the retail investor can reasonably expect to successfully sue an investment firm or a credit institution over its failure to observe a supervision standard will largely depend on how accessible private litigation against such parties in terms of time and costs involved therein is, both domestically and on a cross-border basis, and on how easy it is to obtain relief through the applicable contract or tort law.

As far as retail investors' access to justice is concerned, collective actions and alternative dispute resolution (ADR) mechanisms have a particular role to play here. It is notable that the majority of the Member States currently does not provide for collective redress tools at all. ${ }^{42}$ Across those 13 Member States which do have mechanisms to deal with mass investor claims, these mechanisms differ considerably in relation to their scope, legal standing, opt-in/opt-out, funding and distribution of proceeds.

In Germany, for example, next to a representative action of a more general character under the Legal Services Act (Rechtsberatungsgesetz (RDG)) 2008, where consumers can assign their claims to a consumer association which would bring the cases to court, there is also a specific mechanism for mass investor claims under the Capital Market Model Claims Act (Kapitalanleger-Musterverfahrensgesetz $(K a p M u G)$ ) 2005. The latter was designed as a test case procedure ${ }^{43}$ to strengthen the position of investors in certain disputes under capital markets law. The procedure applies inter alia to multiple investor claims for compensation of damages due to false, misleading or omitted public capital information. Questions of fact and points of law which are the same in at least 10 individual lawsuits for

\footnotetext{
${ }^{41}$ BGH 19 February 2008, BKR 2008, 294, 295.

42 Austria, Bulgaria, Denmark, Finland, France, Germany, Greece, Italy, the Netherlands, Portugal, Spain, Sweden, and the UK. See European Commission-DG SANCO, Study on the Evaluation of the Effectiveness and the Efficiency of Collective Redress Mechanisms in the European Union, 26 August 2008 (referred to below as Evaluation Study Collective Redress), p. 6, available at http://ec.europa.eu/consumers/redress_cons/ collective redress_en.htm\#Studies.

43 After a trial period of 5 years, the Capital Market Model Claims Act will automatically expire on November 1, 2010. If it is found to work adequately, the legislator may decide to extend it or even incorporate its rules into the Code of Civil Procedure. In the latter case, model case proceedings would become generally available in civil litigation. Current comments are positive and demonstrate a tendency towards the extension of the Act. See Country Report Germany in Evaluation Study Collective Redress, Part II (Country Reports), p. 6.
} 
damages are to be combined in model proceedings and decided on a uniform basis by a higher regional court with binding effect for all plaintiffs.

Unlike Germany, the Netherlands, for example, has no specific procedure for bringing mass investor claims. Retail investors may, however, resort to the general procedures for collective redress. Under Dutch law, a foundation or an association representing other persons with the same interest can initiate a collective action in order to obtain a declaratory judgment; damages cannot be awarded in this procedure (art. 3:305 of the Dutch Civil Code). In addition, with the adoption of the Collective Settlement of Mass Damages Act 2005, a collective settlement negotiated between a foundation or an association and the liable party for the payment of damages to be made to all the aggrieved parties can be declared binding on both the liable party and the aggrieved parties by the court, unless they opt-out (art. 7:907of the Dutch Civil Code). According to the study launched by the European Commission into the effectiveness and the efficiency of collective redress mechanisms in the EU, the existing schemes of collective redress generally produce mixed results: while some elements of such schemes work, other do not. ${ }^{44}$

The modalities of the ADR mechanisms, such as ombudsmen, mediators, or complaint boards, also vary considerably across the EU. Some Member States have rather welldeveloped informal dispute resolution bodies, operating as an alternative to private law courts, for disputes related to all financial services sectors, including investment services. The Financial Ombudsman Service in the UK and the Financial Services Complaints Institute (Klachteninstituut Financiële Dienstverlening (Kifid)) in the Netherlands are the examples of such ADR bodies. The existing ADR mechanisms in the investment services sector differ in terms of their character (whether obligatory for investment service providers or not) and procedures. ${ }^{45}$ In a number of Member States, however, ADR schemes in the area of investment services sector are still either non-existent or relatively underdeveloped. This is generally the case, for example, in the new Member States. Moreover, very few Member States have developed collective out-of-court dispute resolution mechanisms. ${ }^{46}$

The need for improving access to justice for consumers, both through the development of collective redress and ADR mechanisms, has been acknowledged on the EU level. In the 2008 Green Paper on Consumer Collective Redress the Commission initiated the assessment of the current state of redress mechanisms with a view to closing any gaps to effective redress identified in such cases. ${ }^{47}$ In its 2009 follow-up consultation paper the Commission contends that "the lack of an effective legal framework enabling consumers to ensure adequate compensation in mass claim cases is detrimental to the market and creates a justice gap." 48 The available policy options described by the Commission range from taking no action in this area to establishing a detailed harmonized EU-wide judicial collective redress mechanism including collective ADR. It remains to be seen which option will ultimately be chosen. At present, however, the only relevant rule in the EC law on collective actions in the investment services field is art. 52(2b) of the MiFID which

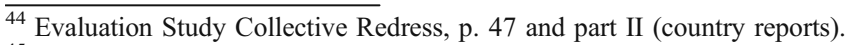

${ }^{45}$ See European Commission Consultation Document on Alternative Dispute Resolution in the Area of Financial Services, Brussels, referred to below as Commission Consultation Document ADR Financial Services, 11 December 2008, available at http://ec.europa.eu/internal_market/consultations/docs/adr/adr_ consultation_en.pdf. See also DG SANCO, Study on the Use of Alternative Dispute Resolution in the European Uñion, 16 October 2009, available at http://ec.europa.eu/consumers/redress_cons/adr_study.pdf.

${ }^{46}$ See Evaluation Study Collective Redress.

${ }^{47}$ Green Paper on Consumer Collective Redress, COM (2008) 794 final.

${ }^{48}$ Follow-up to the Green Paper on Consumer Collective Redress, 8 May 2009, p. 3, available at http://ec. europa.eu/consumers/redress_cons/collective_redress_en.htm\#Consultation.
} 
provides for "a right of appeal" by consumer organizations to "ensure that the national provisions for the implementation of this Directive are applied." Unfortunately, this provision does not define the specific scope and objective of this right.

The improvement of the ADR mechanisms, specifically in the field of financial services, have currently also focused the attention of the EU institutions. In its 2008 resolution on the Green Paper on retail financial services ${ }^{49}$ the European Parliament requested that consumers have access to ADR mechanisms, both at national and cross-border level, and called on the Commission to promote best practices on ADR. In the same year the Commission started a consultation process with a view to improving the effectiveness of national ADR schemes, and hence that of a pan-European financial dispute resolution network of national out-ofcourt complaint schemes established already in 2001-a FIN-NET. ${ }^{50}$ While stakeholders are generally of the view that there is a need to look for ways to improve the possibilities for redress through ADR schemes, opinions differ as to how this can be achieved and at what level (national/EU). ${ }^{51}$ It is also not clear yet what policy options will be pursued by the Commission in this field. It is notable, however, that the foundation of a pan-EU dispute resolution system is already laid down in a public enforcement-oriented MiFID. Art. 53 of this Directive obliges the Member States to "encourage the setting-up of efficient and effective complaints and redress procedures for the out-of-court settlement of consumer disputes concerning the provision of investment and ancillary services provided by investment firms, using existing bodies where appropriate."

As has already been mentioned above, apart from the problem of access to justice, another major issue for a retail investor is how easy he can obtain relief trough the applicable contract or tort law. Even if a particular supervision standard has effect in the relationship of investment service provider and its client, this does not mean yet that the latter will obtain relief. In order to do so, all conditions for liability, rescission or termination of the contract, under the applicable national private law, should be met.

For a successful claim for damages in Dutch contract law, for example, it is not only necessary to establish that there is a violation of a particular supervision standard and that this violation involves the breach of the investment service provider's general duty of care under art. 7:401 of the Civil Code amounting to non-performance (tekortkoming) in the sense of art. 6:74 of the Civil Code. In addition, art. 6:74 requires that the non-performance is imputable to the service provider, that the client has suffered loss and that there is a causal link between the breach of the general duty of care by the service provider and the loss suffered by the client.

As a rule, the burden of proof with regard to all these conditions lies with the aggrieved retail investor. In practice, however, it may not always be easy for the investor to prove them. Particular difficulties may arise concerning the proof of the causal link between the breach of the conduct of business rules and the damage. Proof of a causal link may be difficult, for example, if the investor has suffered loss due to unclear or misleading information, a missing warning of the risks involved in a certain investment or a recommendation to purchase an unsuitable investment product. More investor friendly private law courts in some legal systems tend, therefore, to reverse the burden of proof in certain cases in favour of investors. Thus, for example, in its recent judgment, the German

\footnotetext{
${ }^{49}$ European Parliament resolution of 5 June 2008 on the Green Paper on Retail Financial Services in the Single Market (2007/2287(INI)).

${ }^{50}$ Commission Consultation Document ADR Financial Services.

${ }^{51}$ European Commission, Summary of the Responses to the Public Consultation on Alternative Dispute Resolution in the Area of Financial Services, Brussels, 14 September 2009, available at http://ec.europa.eu/ internal_market/finservices-retail/docs/redress/consultation_summary_en.pdf.
} 
Supreme Court in private law matters adopted a presumption that the aggrieved individual investor would not have made an investment if the investment adviser had provided him with the correct information concerning his kick-back-payments; as a rule, this presumption applies to all cases in which the investment adviser has failed to comply with its duties to inform. ${ }^{52}$ Accordingly, if the violation of the duty to inform by the investment adviser is established, it is up to the adviser to prove that the investor would have concluded the contract even he was duly informed. Reich has recently argued in favour of extending such reverse burden of proof to the (sufficiently) serious violations of the investment service providers' obligations under the MiFID (Reich 2010b).

While it aims to protect investors, the MiFID itself, however, does not contain any rules which would (seek to) improve the retail investor's procedural position by reversing the burden of proof in his favour. It is notable that in contrast to the MiFID, such rules can be found in other directives in the area of financial services.

Thus, for example, according to art. 7(3) of the Distance Marketing of Consumer Financial Services Directive, in those cases where the consumer exercises his right of withdrawal from a distance contract, the supplier may not require the consumer to pay any amount for the service actually provided by the supplier, unless he can prove that the consumer was duly informed about the amount payable. Article 15 of this Directive provides that Member States may also shift the burden of proof to the supplier in respect of other supplier's obligations to inform the consumer set out in this Directive, the consumer's consent to conclusion of the contract, and, where appropriate, its performance. A similar rule can be found in art. 33 of the Payment Services Directive. According to this provision, Member States may stipulate that the burden of proof concerning the compliance with the information requirements laid down in this Directive shall lie with the payment service provider. Moreover, a number of consumer protection rules on burden of proof, which do not allow any discretion for the Member States, are also included in the Draft Directive on Consumer Rights. ${ }^{53}$

As the MiFID, however, does not contain any such rules, it wholly depends on national private laws whether an individual investor's claim arising from the violation of a supervision standard will attract a reverse burden of proof.

\section{What About Investor Duties and the (Shared) Liability Regime?}

Last but not least, consumer rights and consumer responsibilities must go hand-in-hand. In order to benefit from their rights, consumers should normally fulfil certain duties. In the first place, they should comply with certain information and notification obligations to be able to enforce their rights. Moreover, consumers are also expected to make efforts in order to make responsible choices.

Consumer duties are also not something new for EC law. Such duties are contained, for example, in the Draft Directive on Consumer Rights. ${ }^{54}$ Similarly, the Payment Services Directive also imposes certain obligations on consumers in relation to payment instruments. For example, according to art. 56(b) of this Directive, the payment service user should notify the payment service provider without any delay on becoming aware of loss, theft or misappropriation of the payment instrument, or of its unauthorized use. Moreover, as has already been mentioned above, the Payment Services Directive, to a certain extent, also

\footnotetext{
${ }_{52}$ BGH, 12 May 2009, WM 2009, 1274.

${ }^{53}$ E.g., terms presumed to be unfair (art. 35); burden of proof in case of the lack of conformity (Art. 28).

${ }^{54}$ E.g., the consumer's duty to inform the seller in case of the lack of conformity (art. 28 (4)); the obligations of the consumer in case of withdrawal (art. 17).
} 
harmonizes the liability regime. ${ }^{55}$ This Directive even contains a provision on payer's liability: under art. 61(1) of the Directive the payer shall bear the losses relating to any unauthorized payment transactions, up to a maximum of $150 €$, resulting from the use of a lost or stolen payment instrument or, if the payer has failed to keep the personalized security features safe, from the misappropriation of a payment instrument.

A characteristic feature of the EC investment services regulation, however, is its strong focus on the duties of investment service providers and the absence of the liability regime. The role of the client in the investment service process is hardly dealt with therein. For example, the MiFID does not explicitly lay down the investor's duty to study information provided to him by the investment firm or the duty to provide the investment firm with correct information regarding his knowledge and experience in the investment field, his financial situation and his investment objectives. While these duties of the investor essentially correspond to the obligations of the investment firm to provide the investor with appropriate information under art. 19(3) and to assess the suitability of a particular investment service or financial instrument under art. 19(4) of the MiFID, respectively, the Directive does not address the issue of the legal consequences of a failure to observe his own duties for the investor.

Such an approach may give an impression that the violation of a particular supervision standard in the investment service provider-client relationship will always lead to the full liability of an investment firm or a credit institution provided that the conditions of such liability are met. Yet, in many legal systems, the (potential) client may be held partially liable for his loss.

This is the case, for example, in Dutch law where the core principal of tort law, according to which everybody has to bear his damage, is considerably restricted as a result of introducing the shared liability of banks and their clients for compliance with the applicable rules, including those which form part of the financial supervision legislation. This follows, for instance, from the decision of the Dutch Supreme Court in the Kouwenberg v. Rabobank case. ${ }^{56}$ According to the Supreme Court, even if the bank violates its duty of care towards the client by yielding to the client's explicit wish to execute his order despite a lack of sufficient securities, the client may be held liable for a part of the losses if they were caused by his own fault (eigen schuld); this may be the case if the client was aware of the fact that his transactions in options ${ }^{57}$ did not comply with the margin requirements, ${ }^{58}$ but nevertheless failed to close out his positions and to refrain from entering into new transactions. Recently, the Supreme Court also imposed shared liability on the bank and its client in the De T. v. Dexia Bank Nederland N.V. case. ${ }^{59}$ In this case, the retail investor who financed the purchase of financial instruments with borrowed money suffered substantial losses. It was established that the bank failed to comply with its private law duty to know its client and to warn him about the risks involved in investing with borrowed money (effectenlease). Yet, the retail investor was held liable for $40 \%$ of his losses, as, according to the Supreme Court, he had failed to make a reasonable effort to

\footnotetext{
55 See arts. 60-61 (liability for unauthorized payment transactions) and arts. 74-78 (liability for nonexecution or defective execution of payment transactions).

${ }^{56}$ HR 11 July 2003, NJ 2005, 103.

${ }^{57}$ Options are financial instruments that convey the right to engage in a future transaction on some underlying security, such as shares or bonds.

${ }^{58}$ Margin requirement is the minimum amount in the form of cash or eligible securities that an investor must deposit in a margin account before buying or selling positions in options.

${ }^{59}$ HR 5 June 2009, RvdW 2009, 683. See also HR 5 June 2009, RvdW 2009, 684 (Levob Bank N.V. v. B, and $G B D)$.
} 
understand the meaning of effectenlease, while the risks involved therein were made sufficiently clear in the contract concluded by him.

In the absence of clear rules on investor duties and liabilities, the aggrieved investor who has succeeded in establishing the violation of a particular conduct of business rule still faces uncertainty as to his own share of losses. Such a prospect may deter retail investors from bringing actions against investment service providers. Moreover, the lack of harmonization in this area may also negatively affect the establishment of the single market in investment services and products. It is unfortunate, therefore, that in its recent 2010 Communication on Regulating Financial Services for Sustainable Growth the Commission commits itself to promoting convergence of sanctions solely across the range of supervisory activities in the financial sector without even acknowledging the importance of such convergence in the area of civil liability. ${ }^{60}$

\section{Towards Investor Empowerment?}

It follows from the foregoing that the violation of the conduct of business rules does not eo ipso lead to the liability in private law. The private law concepts still largely provide the basis for the investment firm's or credit institution's liability for a breach of its duties of care towards the retail investor, and hence determine whether there is a violation of a duty of care in private law and, if so, what are the consequences - if any - of such a violation for the investment service provider and the investor. In some respects, this situation can be explained by the multi-level system of governance in the EU and the principle of procedural autonomy of the Member States. ${ }^{61}$ At the same time, a great deal of uncertainty concerning the consequences of the violation of the contact-related standards contained in the MiFID in the investment service provider-client relationship is caused by the supervisory nature of these rules and their implementation into the public law legislation in the Member States. This fact makes it much more difficult to grasp whether a particular supervision standard has effect in private law and, if so, what remedies are available to the (potential) client in case of its violation by the investment service provider.

The fact that the EU legislator places strong emphasis on public enforcement in the investment services field is disturbing because private enforcement by individual investors or their groups is also important for the ability of the EC securities regulation to attain its policy goals. ${ }^{62}$ As Moloney observes (Moloney 2007, p. 425):

"Market mechanisms which promote good behaviour by investment firms depend, in part, on the active policing by investors of firm failures, particularly with respect to investment advice. The development of an effective retail investor constituency includes, therefore, the development of a cohort of investors empowered, and sufficiently informed, to monitor investment firms (...) and to exercise liability rights, whether contractual or otherwise."

Besides, it remains to be seen whether and, if so, to what extent, supervisory authorities, which are primarily concerned with protecting the general interest, will play a role in

\footnotetext{
${ }^{60}$ Commission Communication to the European Parliament, the Council, the European Economic and Social Committee and the European Central Bank on Regulating Financial Services for Sustainable Growth, COM (2010) 301 final, p. 6.

${ }^{61}$ See, in particular, a study by Reich into the relationship between rights and obligations of private parties in EU law: Reich 2010a, b.

${ }^{62}$ On the importance of an effective retail investor enforcement in Europe see, e.g., Black 2001; Coffee 2004; Moloney 2007.
} 
protecting the individual investor interests. It is the combination of public and private enforcement which is necessary to ensure the effectiveness of the legal standard in practice. $^{63}$ At the moment, the private enforcement of the EC securities regulation, however, heavily depends on national private laws. It is not entirely clear therefore to what extent aggrieved investors will really benefit from the extensive conduct of business rules introduced by the EC securities regulation, and thus to what extent the latter will be able to ensure a high level of investor protection.

As the European Commission itself acknowledges, good investor protection rules do not guarantee good investment decisions. ${ }^{64}$ The existence of such rules alone is not sufficient to secure a high level of investor protection; legal rules should be supplemented by other measures, such as retail investor education and the promotion of retail investor governance. ${ }^{65}$ The need for such measures, however, does not replace the need for the establishment of a comprehensive legal framework which would provide retail investors with both rights and remedies vis-à-vis investment service providers.

\section{The Role of Private Law in Protecting Retail Investors}

\section{A Two-Tier Legal Framework}

In fact, the conduct of business rules, which now form part of the EC regulatory framework for investment services, have largely originated within the national private laws, in particular contract laws of the Member States, and, primarily with a view to strengthening investors' confidence in the financial market, have been casted as supervision standards and strengthened by public law enforcement mechanisms in the financial supervision legislation. ${ }^{66}$ Thus, for example, the provider's duty to know one's client when providing investment advice, which is now included in art. 19(4) of the MiFID, largely corresponds to the rules earlier established in the Bond case decided by the German Supreme Court in private law matters (Bundesgerichtshof) in 1993. ${ }^{67}$ What implications, however, does the publicization of the private law duties of care have for the role of private law, in particular purely private law duties of care, in protecting nonprofessional investors today? May the latter still rely on the investment service providers' duties of care in private law? ${ }^{68}$

It is notable that at the time of drafting the MiFID, the Committee on Economic and Monetary Affairs of the European Parliament justified one of its amendments to the MiFID by the need to prevent investment service providers from being subject to a

\footnotetext{
${ }^{63}$ For well-articulated arguments in favour of such an approach in the law and economic literature, see, e.g., Kolstad et al. 1990; Shavell 1984, 2004. Cf. Rose-Ackerman 1991.

${ }^{64}$ Commission Communication on PRIP, p. 5. See also Communication from the Commission to the Council, the European Parliament and the European Economic and Social Committee on EU Consumer Policy Strategy 2007-2013: Empowering Consumers, Enhancing Their Welfare, Effectively Protecting, COM (2007) 99 final.

${ }^{65}$ On a "multi-stranded strategy for the retail markets," see Moloney 2007.

${ }^{66}$ On this development in German, Dutch and English Law in more detail, see Cherednychenko 2007, chs. 7 \& 8. Cf. Grundmann 2005, p. 490. On a similar development in Belgian law, see Colaert 2010.

${ }^{67}$ BGH 6 July 1993, BGHZ 123, 126=NJW 1993, 2433 (Bond).

${ }^{68}$ On the role of private law in the investment service provider-client relationship after the introduction of the (EC) conduct of business rules in more detail, see Cherednychenko 2009.
} 
"double layer of regulation" in some Member States, such as Germany, where "much investor protection is carried out via civil liability in the courts." ${ }^{\circ}$ The proposed amendment was meant to make clear that the "new EU framework supersedes traditional pre-existing civil liability,"70 so that the private law rules may not undermine the new supervision standards. ${ }^{71}$

It is highly doubtful, however, whether any significant importance can be attached to these remarks, considering that the MiFID itself is silent upon the issue of the relationship between the regulatory standards contained therein and national private laws. Considering that the MiFID is drafted from the perspective of ensuring effective supervision over the investment services industry, it does not seem plausible to assume that conduct of business rules are lex specialis as against general private law rules, in the same way as are, for example, consumer protection provisions. The nature of the conduct of business rules makes it possible to conclude that private law duties of care have not been overruled by the public law duties of care contained in the supervision legislation. Accordingly, by casting many rules which are relevant for the private law relationship between the investment service provider and the retail client, the EU legislator created a two-tier legal framework, consisting of private law, on the one hand, and public law, on the other.

\section{The Relationship between Supervision Standards and Private Law Rules}

The emergence of the two-tier legal framework for the provision of investment services gives rise to the question of how the two sets of substantive rules relate and should relate to each other. ${ }^{72}$ The crucial issue here is to what extent private law can maintain and develop purely private law rules, in particular, duties of care, independently from the conduct of business rules, considering the latter's maximum harmonization under the MiFID.

This issue is not of a purely theoretical interest, as by no means all private law duties of care currently in force in the Member States correspond to the new supervision standards implementing the MiFID. Thus, for example, the requirement established by the German Supreme Court in the Bond case that in providing investment advice the bank must also cover the specific risks involved in the recommended financial instruments ${ }^{73}$ exceeds the bank's conduct of business obligations under arts. 19(3) and (4) of the MiFID. ${ }^{74}$ Similarly, the Dutch private law courts hold investment firms and credit institutions under the broad duty to know their client in those cases where complex and risky investment products or

\footnotetext{
${ }^{69}$ Report of the Committee on Economic and Monetary Affairs of the European Parliament of 4 September 2003 on the proposal for a European Parliament and Council Directive on investment services and regulated market, and amending Council Directives 85/611/EEC, Council Directive 93/6/EEC and European Parliament and Council 2000/12/EC (COM (2002) 625-C5-0586/2002-2002/0269(COD)), amendment no. 23 .

${ }^{70}$ Ibid.

${ }^{71}$ While the rationale for the amendment was to clarify the relationship between the contract-related supervision standards contained in the MiFID and national private laws in general, the proposed amendment though was made only in the context of the MiFID provision on client classification and merely contained suggestions as to the clearer definitions of "professional client" and "retail client." These suggestions were included in the final text of the MiFID.

72 On the relationship between supervision standards and private law in more detail, see Cherednychenko 2009.

${ }^{73}$ BGH 6 July 1993, BGHZ 123 (Bond).

${ }^{74}$ Under art. 19(3) and (4) of the MiFID, investment service providers are free from any obligation to provide information on specific risks associated with investment in particular financial instruments. Cf. Mülbert 2007, p. 317.
} 
services are involved, without distinguishing between different types of investment services (execution-only, investment advice or portfolio management). ${ }^{75}$ In all such cases investment service providers are obliged to collect information, in particular, about the client's financial situation and investment objectives. ${ }^{76}$ Consequently, contrary to art. 19(5) of the MiFID, which does not impose such an extensive duty to know one's client on investment firms and credit institutions providing execution-only services, ${ }^{77}$ the investment firm or credit institution providing such service may nonetheless find itself bound by it ex post under Dutch private law.

As a result of the silence of the MiFID upon the issue of the relationship between the regulatory standards contained therein and national private laws, and the MiFID's focus upon ensuring effective supervision over the investment services industry, the issue in question has largely been left to national private law courts and alternative dispute resolution boards in the financial services field (if such are in place) to decide.

At present, the judicial authority on the issue of the relationship between supervision standards and private law rules is scarce. The dicta available so far in the UK and the Netherlands, for example, acknowledge the impact of the supervision standards upon the private law concepts, but at the same time emphasize the autonomy of private law and private law adjudication in relation to these standards.

Thus, in the decision of the Court of Appeal in Gorham v. British Telecommunications $p l c{ }^{78}$ Lord Justice Pill, with whom the other two judges agreed on this point, rejected a submission by the applicant, Mr Plamer, that the detailed statutory scheme for investor protection created by the Financial Services Act 1986-the forerunner of the Financial Services and Markets Act 2000 currently in force-precluded the court from developing a common law tortious claim that went beyond the statutory code. As Lord Justice Pill put it:

"Mr Plamer rightly accepts the pressing need which developed in the 1980s for a statutory framework within which financial services could be provided. I do not however discern a Parliamentary intention to eliminate the power of courts to decide whether a duty of care arises in a particular situation and, if so, what its extent is. Had Parliament not intervened, remedies for the abuses which existed in this field would almost certainly have been developed by the courts. The courts now do so in the context, and with the benefit of, rules and codes of practice laid down by those concerned with the maintenance of proper standards. The courts can be expected to

\footnotetext{
${ }^{75}$ The most limited type of investment services consists of the supply of execution-only investment services. Such services consist only of the execution and/or reception and transmission of client orders by a firm or a credit institution upon the specific instructions of a client, with or without ancillary services. The involvement of an investment firm or a credit institution goes further if investment services are provided on the basis of the advisory relationship between the parties. In such a case, an investment service is not limited to the execution and/or reception and transmission of the client's orders, but also includes the provision of investment advice. On the basis of such advice the client makes an investment decision. The most extensive type of investment services is discretionary management of the client's portfolio. In such a case, one can speak about a portfolio-management relationship between the parties, in which the investor entrusts the investment service provider with the management of his assets or a part thereof.

76 See, for example, District Court of Den Bosch, 9 May 2006, LJN: AX2464.

${ }^{77}$ Under art. 19(5) of the MiFID, when providing investment services in complex financial instruments on the execution-only basis, investment firms or credit institutions should only ask the client to provide information about his knowledge and experience in the investment field relevant to the specific type of product or service offered or demanded (the so-called 'appropriateness test).

${ }^{78}$ Gorham \& Others v. British Telecommunications plc, Trustees of the BT Pension Scheme, \& Standard Life Assurance Company [2000] 1 WLR 2129.
} 
attach considerable weight to the content of codes drafted in these circumstances but are not excluded from making their own assessment of a situation."79

The message from the Court of Appeal is thus that the conduct of business rules are to assist the courts in determining what are appropriate standards of care in negligence actions; at the same time, these rules do not extend to limiting the courts' ability to develop principles as to whom the duty of care is owed, something which the courts are perfectly capable of doing on a purely common law basis.

A similar view has also recently been taken by the Dutch Supreme Court in the cases, De T. v. Dexia Bank Nederland N.V., Levob Bank N.V. v. B, and GBD and Stichting Gedupeerden Spaarconstructie v. Aegon Nank N.V. ${ }^{80}$ In these cases, the banks submitted that at the time the contract between them and their clients was concluded, the duty to know one's client had not been included in the financial supervision legislation then in force. ${ }^{81}$ Hence, the banks argued, they could expect that by complying with the public law standards, they had also been acting in conformity with the duty of care in private law. In all three cases, this line of reasoning was, however, unequivocally rejected by the Supreme Court which held that the private law duties of care can go further than the public law duties of care contained in the conduct of business rules. In doing so, the Supreme Court followed the opinion of the Advocate General in these cases who argued as follows:

"The argument of the banks referred to above does not take into consideration the fact that although when determining the scope of the bank's special duty of care, which follows from the requirements of good faith, the content of the public law legislation may be taken into account, it is untenable to claim that this private law duty of care may not go further than the conduct of business rules contained in the public law legislation. Adopting such an approach would ignore the fact that the Netherlands has a system of double duties of care - the public law duties of care and the private law duties of care (primarily developed by the Supreme Court). The public law supervision legislation aims to safeguard a diligent, professional and honest conduct of business by an investment firm (and/or a credit institution) and, to this end, it contains further rules on the basis of which a supervisory authority can promote these goals. The requirements of good faith as well as that which can be imposed upon a good service provider are tailored to an individual case and may entail that a financial service provider is under a further-reaching duty of care than that following from the public law legislation in force at that time; this is so because the public law duty of care influences the private law duty of care but does not determine it." 82

When assessing the implications of these pronouncements in practice, one should take into account that neither the decision of the English Court of Appeal nor the opinion of the Advocate General of the Dutch Supreme Court were given in relation to the conduct of business rules implementing the maximum harmonization regime of the MiFID. While the decision of the Court of Appeal predates not only the MiFID but also the ISD, the opinion

\footnotetext{
${ }^{79}$ [2000] 1 WLR 2129, 2141.

${ }^{80}$ HR 5 June 2009, RvdW 2009, 693, 684 and 685.

${ }^{81}$ The Securities Transactions Supervision Decree (Besluit toezicht effectenverkeer) 1995 and the Further Regulations on Market Conduct Supervision of the Securities Trade (Nadere Regeling gedragstoezicht effectenverkeer) 1995 and 1999.

${ }^{82}$ The Opinion of the Advocate General of 13 February 2009 in Levob Bank N.V. v. B, and GBD, De T. v. Dexia Bank Nederland N.V., and Stichting Gedupeerden Spaarconstructie v. Aegon Nank N.V., para. 3.21 (translation and italics added).
} 
of the Advocate General is expressed in the context of the conduct of business rules implementing the minimum harmonization regime of the ISD.

Yet, in my view, the autonomy of private law and private law adjudication from supervision standards and decisions of supervisory authorities can also be defended by similar arguments under the MiFID regime. ${ }^{83}$ The MiFID, read in conjunction with the principle of loyalty to the Community laid down in article 10 of the EC Treaty, can hardly be understood in such a way that the national rules implementing it directly shape the private law relationship of investment firm or credit institution and its client. As long as private law plays a role of a mediator of the effect of standardized supervision standards in this private law relationship, it is questionable indeed whether private law should follow these standards in each individual case. It is not unthinkable that at times, the logic of the EU policy driven supervision standards and the logic of the largely unharmonized general private law may clash. For example, applying the rigid classification of clients into "professional," "retail," and "eligible counterparties" set out in the MiFID and adjusting the otherwise applicable private law standard of care to the supervision standard pertaining to the established client category may not necessarily do justice in the circumstances of the individual case. Hence, it is not excluded that in some cases, private law courts will review the behaviour of investment firms ex post on the basis of the general private law duties of care which offer more or less protection to the investor than the maximum harmonization conduct of business rules contained in the MiFID. Under the current public enforcement-oriented EC legal regime for investor protection it is particularly important that private law has the ability to go further in protecting retail investors than financial supervision law.

Denying private law and private law courts a certain degree of autonomy from supervision standards and supervisory authorities involves risks, considering that the effectiveness of the EC legal framework for investment services still needs to be proved (Moloney 2007). While the EU regulatory strategy for the retail investment market, as expressed in the MiFID conduct of business regime, aims to produce well informed and active investors who are able to make autonomous investment choices, the exclusive character of financial supervision regulation as the retail markets strategy also carries significant risks given inter alia the largely untried nature of supervision standards and unpredictable changes in market behaviour. Private law and private litigation have an important role to play as the last resort to those seeking protection should the regulation fail. In fact, "every private law case may be seen as a failure of regulation" (Wilhelmsson 2007, p. 11).

\section{Concluding Remarks}

The analysis of the MiFID framework for the provision of investment services raises serious concerns about its ability to empower retail investors to make active use of their rights. While the MiFID aims to attain a high level of investor protection, which is also an important prerequisite for attaining other two regulatory objectives - the stability and efficiency of the financial system and the market integration, an individual retail investor is pushed into the background in this Directive. Being primarily concerned with the public

\footnotetext{
${ }_{83}$ In this sense in German literature also Fuchs 2009, pp. 1195, 1388, with further references; Koller 2006, p. 840; in Dutch literature also Tjong Tjin Tai and Van den Berg 2009, p. 163. For an alternative view see, in particular, Mülbert 2007, p. 318.
} 
enforcement of the investor protection rules and their maximum harmonization, the MiFID does not sufficiently address the needs of individual retail investors in different EU Member States. It is highly doubtful, therefore, whether extending the MiFID provisions on conduct of business rules to all packaged retail investment products proposed by the European Commission will indeed improve investor rights and restore confidence of retail investors in the financial markets.

As long as the EC securities regulation predominantly focuses on the supervision over investment services industry, the extent of retail investor protection and empowerment will significantly depend on national private laws. In the absence of truly investor-oriented rules at EC level, national private laws should be able to develop autonomously from the EC supervision standards in order to retain the potential to discover and address problems encountered by individual investors when dealing with investment firms.

It would be worthwhile, however, to take the rights of retail investors and their ability to make use of them more seriously within the EC legal framework for the provision of investment services. More generally, the role of private law within this legal framework and the interplay between supervision standards and private law rules deserve much more attention. Concern for the public enforcement of investor protection rules should not replace concern for their private enforcement altogether.

One of the issues, which requires further research, is whether it was actually reasonable to cast the standards highly relevant to investor protection within the investment service provider-client relationship as supervision standards, placing them outside the private law system and creating a tension between the two. In this context it may be useful, for example, to investigate to what extent investment service contracts and the regulatory standards related thereto would fit into the Draft Common Frame of Reference (DCFR; Study Group on a European Civil Code and the Research Group on EC Private Law (Acquis Group) 2009), in particular the principles of European Law on Service Contracts (PELSC) contained in Book IV, Part C (Services) of the DCFR (Cherednychenko and Jansen 2008).

The current overhaul of the EC legal framework for the provision of investment services provides a good opportunity to put an individual retail investor to the forefront and to improve investor protection, not only in words, but in deeds also.

Open Access This article is distributed under the terms of the Creative Commons Attribution Noncommercial License which permits any noncommercial use, distribution, and reproduction in any medium, provided the original author(s) and source are credited.

\section{References}

Black, B. (2001). The legal and institutional preconditions for strong securities markets. UCLA Law Review, $48,781-855$.

Cherednychenko, O. O. (2007). Fundamental rights, contract law and the protection of the weaker party: A comparative analysis of the constitutionalisation of contract law, with emphasis on risky financial transactions. Munich: Sellier.

Cherednychenko, O. O. (2009). European securities regulation, private law and the investment firm-client relationship. European Review of Private Law, 17, 923-950.

Cherednychenko, O. O. (2010). Securities law. In F. Cafaggi, O. O. Cherednychenko, M. Cremona, K. Cseres, L. Gorywoda, R. Karova, H.-W. Micklitz, \& K. Podstawa (Eds.), Europeanization of private law in Central and Eastern Europe countries (CEECs): Preliminary findings and research agenda. EUI Working Papers, Law, forthcoming. 
Cherednychenko, O. O., \& Jansen, C. E. C. (2008). Principles of European law on financial service contracts? European Review of Private Law, 16, 443-468.

Coffee, J. C. (2004). Gatekeeper failure and reform: The challenge of fashioning relevant reforms. In G. Ferrarini, K. J. Hopt, J. Winter, \& E. Wymeersch (Eds.), Reforming company and takeover law in Europe (pp. 455-506). Oxford: Oxford University Press.

Colaert, V. (2010). De meerlagige rechtsverhouding financiële dienstverlener-belegger: Een onderzoek naar de verhouding tussen de MiFID gedragsregels, consumentenrecht en burgerlijk recht, getoetst aan de regels inzake pretransactionele informatieverplichtingen. Doctoral thesis, Leuven, unpublished.

Ferrarini, G. (2005). Contract standards and the Markets in Financial Instruments Directive (MiFID): An assessment of the Lamfalussy regulatory architecture. European Review of Contract Law, 1, 19-43.

Fuchs, A. (2009). Wertpapierhandelsgesetz (WpHG): Kommentar. Munich: Beck.

Grundmann, S. (2005). EC financial services: Developments 2002-2005. European Review of Contract Law, $1,482-494$.

Grundamann, S., \& Hollering, J. (2008). EC financial services and contract law-developments 20052007. European Review of Contract Law, 4, 45-64.

Grundmann-van de Krol, C. M. (2002). Het effectenrecht tussen publiek- en privaatrecht. Den Haag: Boom Juridische uitgevers.

Koller, I. (2006). Die Abdingbarkeit des Anlegerschutzes durch Information im europäischen Kapitalmarktrecht. In T. Baums, M. Lutter, K. Schmidt, \& J. Wertenbruch (Eds.), Festschrift für Ulrich Huber zum siebzigsten Geburtstag (pp. 821-839). Tübingen: Mohr Siebeck.

Koller, I. (2009). Abschnitt 6: Verhaltenspflichten, Organisationspflichten, Transparenzpflichten, Verjährung von Ersatzansprüchen. In H. D. Assmann \& U. H. Schneider (Eds.), Wertpapierhandelsgesetz: Kommentar (pp. 1252-1577). Köln: Verlag Dr. Otto Schmidt.

Kolstad, C. D., Ulen, T. S., \& Johnson, G. V. (1990). Ex post liability for harm vs. ex ante safety regulation: Substitutes or complements? The American Economic Review, 80, 888-901.

Köndgen, J. (1998). Rules of conduct: Further harmonisation? In G. Ferrarini (Ed.), European securities markets: The investment services directive and beyond (pp. 115-130). London: Kluwer Law International.

Micklitz, H.-W. (2004). Anlegerschutz-analyse des EG-rechts. In J. Keßler \& H.-W. Micklitz (Eds.), Anlegerschutz in Deutschland, Scweiz, Großbritannien, USA und der Europäischen Gemeinschaft (pp. 267-325). Baden-Baden: Nomos Verlagsgesellschaft.

Moloney, N. (2007). Effective policy design for the retail investment services market: Challenges and choices post FSAP. In G. Ferrarini \& E. Wymeersch (Eds.), Investor protection in Europe: Corporate law making, the MiFID and beyond (pp. 381-441). Oxford: Oxford University Press.

Mülbert, P. O. (2007). The eclipse of contract law in the investment firm-client-relationship: The impact of the MiFID on the law of contract from a German perspective. In G. Ferrarini \& E. Wymeersch (Eds.), Investor protection in Europe: Corporate law making, the MiFID and beyond (pp. 299-320). Oxford: Oxford University Press.

Reich, N. (2010a). Rights without duties? Reflections on the state of liability in the multilevel governance system of the Community: Is there a need for a more coherent approach in European private law? EUI Working Papers, Law 2009/10.

Reich, N. (2010b). The interrelationship between rights and duties in EU law. In P. Eeckhout \& T. Tridimas (Eds.), Yearbook of European Law 2010. Oxford: Oxford University Press. forthcoming.

Rose-Ackerman, S. (1991). Tort law in the regulatory state. In P. H. Schuck (Ed.), Tort law and the public interest - competition, innovation, and consumer welfare (pp. 80-102). New York: W. W. Norton.

Shavell, S. (1984). A model of the optimal use of liability and safety regulation'. The Rand Journal of Economics, 15, 271-280.

Shavell, S. (2004). Foundations of economic analysis of law. Harvard: Belknap.

Study Group on a European Civil Code, \& the Research Group on EC Private Law (Acquis Group). (2009). Principles, definitions and model rules of European private Law: Draft Common Frame of Reference (DCFR). Munich: Sellier. Interim outline edition.

Tison, M. (2002). Conduct of business rules and their implementation in the EU Member States. In G. Ferrarini, K. J. Hopt, \& E. Wymeersch (Eds.), Capital markets in the age of the euro: cross-border transactions, listed companies and regulation (pp. 65-100). The Hague: Kluwer Law International.

Tjong Tjin Tai, T. F. E., \& Van den Berg, M. F. M. (2009). Financiële zorgplichten van de verzekeraar bij beleggingsproducten. Aansprakelijkheid, Verzekering \& Schade, 9, 163-172.

Van Baalen, S. B. (2007). De honderd ogen van Argus: Aansprakelijkheid als gevolg van schending van financiële regels. In D. Busch et al. (Eds.), Onderneming en financieel toezicht (pp. 661-675). Deventer: Kluwer.

Wilhelmsson, T. (2007). The paradox of the risk society and the fragmentation of consumer law. In I. Ramsay, J. Salloum, N. Horrox, \& G. Mowatt (Eds), Risk and choice in consumer society (pp. 1-21). Athènes: Ant. N. Sakkpulas. 